\title{
Korekce chyb srážek a teploty z regionálních klimatických modelů - vliv na modelování odtoku
}

MARTIN HANEL, ROMAN KOŽíN

Klíčová slova: korekce chyb - kvantilová metoda - klimatické scénáře - modelování odtoku

\section{SOUHRN}

Pro odhad vlivu změny klimatu na vodní režim v krajině a sektory vodního hospodářství se zpravidla užívá hydrologického modelování, kde vstupem do hydrologického modelu jsou scénářové srážky a teploty založené na simulacích klimatických modelů. Tyto simulace jsou zatíženy systematickými chybami, které Ize korigovat pomocí řady dostupných metod. Nicméně se ukazuje, že shoda rozdělení korigovaných a pozorovaných vstupních veličin (srážek a teploty) nezaručuje shodu rozdělení simulovaného odtoku. To je způsobeno zejména skutečností, že běžně používané metody korekce systematických chyb klimatických modelů neodstraňují chyby v časové struktuře srážek. Dalším problémem je, že korekce se zpravidla omezují na časové měřítko, v němž je (hydrologický) model provozován - tj. většinou denní. Ukazuje se, že pres uspokojivou korekci veličin v denním časovém kroku jsou měsíční, sezonní a roční agregace srážek zatíženy podstatnou systematickou chybou, což následně vede k chybám v dlouhodobé hydrologické bilanci a variabilitě simulovaného odtoku.

\section{ÚVOD}

Jelikož jsou simulace klimatických modelů zatíženy systematickými chybami, nelze simulované časové řady srážek a teploty použít prímo pro hydrologické modelování. Relativně hrubé horizontální rozlišení globálních i regionálních klimatických modelů (RCM) neumožňuje adekvátně popsat orografii terénu, vznik konvektivních srážek atp. $V$ důsledku toho je řada jevů popsána pomocí empirických nebo semi-empirických vztahů, které jsou často zmiňovány jako jedna z dominantních prríčin systematických chyb v simulacích klimatických modelů [1-3].

Existuje řada studií, které se zabývají korekcí chyb klimatických modelů. Korekce simulovaných srážek a teploty spočívá v transformaci simulovaných časových řad takovým způsobem, který zaručí prijiatelnou shodu vybraných statistických charakteristik simulovaných a pozorovaných veličin. Byly vyvinuty různé metody korekce systematických chyb, od transformací korigujících prüměr pres nelineární transformace korigující průměr a variabilitu až po pokročilé metody transformující celé rozdělení pravděpodobnosti uvažovaných veličin, popř. vztahy mezi proměnnými. Tyto metody představuje např. [4-6]. Řada aspektů korekce systematických chyb je však problematická, viz např. [7, 8].

Simulace RCM jsou zpravidla k dispozici v denním časovém kroku. $V$ tomto časovém měřitku také probíhá korekce simulovaných veličin i hodnocení její účinnosti. Současné metody korekce systematických chyb jsou schopné transformovat simulovaná data tak, že rozdělení korigovaných veličin se perfektně shoduje s rozdělením veličin pozorovaných a navíc rozumně zachovává korelační strukturu mezi veličinami. Shoda rozdělení a vztahů veličin v denním kroku však neznamená shodu v případě delších či kratších časových měřítek, což je způsobeno časovou strukturou simulovaných veličin, která není zpravidla korekcí ovlivněna. Toto chování bylo popsáno např. v pracích Haerter aj. [9], Johnson a Sharma [10], Ehret aj. [7] a Addor aj. [8], nicméně ve většině praktických aplikací je tento problém často přehližen. Hodnocení metod korekce se navíc často omezuje na veličiny simulované klimatickým modelem (např. srážky a teplota) a neuvažuje výstupy závislé na těchto veličinách (např. odtok).

$\checkmark$ predkládaném článku jsou proto demonstrovány základní problémy korekce systematických chyb při použití v hydrologických simulacích. Ukazuje se, že rozdělení odtoku simulovaného pomocí hydrologického modelu využívajícího korigované srážky a teplotu neodpovídá rozdělení odtoku simulovaného na základě pozorovaných časových řad ani v časovém kroku, ve kterém byla korekce provedena. Pro analýzu účinnosti metod korekce systematických chyb na různé veličiny v různých časových měřítcích byl vyvinut balík MUSICA pro R software, viz https://github.com/hanel/musica.

\section{POPIS OBLASTI A DATA}

Studie byla provedena na povodí Oslavy, které má rozlohu 861 km² s průměrnou výškou 500 m n. m. Průměrná roční srážka činí 594 mm, průměrná teplota $7,2^{\circ} \mathrm{C}$ a průměrný průtok v ústí je $3,5 \mathrm{~m}^{3} / \mathrm{s}$. Povodí je z větší části neregulované, pouze na horním toku Oslavy je víceúčelová vodárenská nádrž Mostiště. Nevyskytují se zde vyšší elevace, které by znesnadňovaly použití RCM.

\section{Pozorovaná data}

Pro studii byla použita hydrometeorologická data (srážky, teplota, průtoky) v denním kroku z období 1970-1999. Časové řady srážek a teploty pocházejí z interpolovaných dat do pravidelné sítě $25 \times 25$ km [11], průtoky pak z vodoměrné stanice Oslavany. 
Tabulka 1. Použité RCM simulace; v rádcích jsou uvedeny rídicí simulace globálních klimatických modelü, sloupce odpovídají regionálním klimatickým modelům; v jednotlivých buňkách je v závorkách uveden počet simulací podle RCP2.6 („26"), RCP4.5 (,45") a RCP8.5 („85")

Table 1. Considered RCM simulations; driving GCM simulations are listed in rows whereas columns correspond to RCMs; a number of simulation according to RCP2.6 (,26"), $R C P 4.5\left({ }_{1 \prime} 45^{\prime \prime}\right)$ and $R C P 8.5\left({ }_{1 \prime}, 85^{\prime \prime}\right)$ is listed in brackets in individual cells

\begin{tabular}{|c|c|c|c|c|c|c|c|c|}
\hline GCM & $\begin{array}{l}\text { CLMcom- } \\
\text {-CCLM4-8-17 }\end{array}$ & $\begin{array}{c}\text { CNRM- } \\
\text {-ALADIN53 }\end{array}$ & $\begin{array}{c}\text { DMI- } \\
\text { HIRHAM5 }\end{array}$ & $\begin{array}{c}\text { HMS- } \\
\text {-ALADIN52 }\end{array}$ & $\begin{array}{c}\text { IPSL- } \\
\text {-INERIS- } \\
\text {-WRF331F }\end{array}$ & $\begin{array}{c}\text { KNMI- } \\
\text {-RACMO22E }\end{array}$ & $\begin{array}{l}\text { SMHI- } \\
\text {-RCA4 }\end{array}$ & $\mathbf{N}$ \\
\hline CCCma-CanESM2 & & & & & & & $45(1), 85(1)$ & 2 \\
\hline $\begin{array}{l}\text { CNRM-CERFACS- } \\
\text {-CNRM-CM5 }\end{array}$ & $45(1), 85(1)$ & $45(1), 85(1)$ & & $85(1)$ & & & $45(2), 85(2)$ & 9 \\
\hline $\begin{array}{l}\text { CSIRO-QCCCE- } \\
\text {-CSIRO-Mk3-6-0 }\end{array}$ & & & & & & & $85(1)$ & 1 \\
\hline ICHEC-EC-EARTH & $45(1), 85(1)$ & & $45(1), 85(1)$ & & & $45(1), 85(1)$ & $\begin{array}{l}26(2), 45(2) \\
85(2)\end{array}$ & 12 \\
\hline IPSL-IPSL-CM5A-MR & & & & & $45(1), 85(2)$ & & $45(2), 85(2)$ & 7 \\
\hline MIROC-MIROC5 & & & & & & & $45(1), 85(1)$ & 2 \\
\hline MOHC-HadGEM2-ES & $45(1), 85(1)$ & & & & & $45(1), 85(1)$ & $\begin{array}{l}26(1), 45(2) \\
85(2)\end{array}$ & 9 \\
\hline MPI-M-MPI-ESM-LR & $45(1), 85(2)$ & & & & & & $\begin{array}{c}26(1), 45(2) \\
85(2)\end{array}$ & 8 \\
\hline NCC-NorESM1-M & & & & & & & $85(1)$ & 1 \\
\hline $\begin{array}{l}\text { NOAA-GFDL- } \\
\text {-GFDL-ESM2M }\end{array}$ & & & & & & & $85(1)$ & 1 \\
\hline rсp26 & 0 & 0 & 0 & 0 & 0 & 0 & 3 & 3 \\
\hline rcp45 & 4 & 1 & 1 & 0 & 1 & 2 & 12 & 21 \\
\hline rcp85 & 4 & 1 & 1 & 1 & 2 & 2 & 15 & 26 \\
\hline VŠE & 8 & 2 & 2 & 1 & 3 & 4 & 30 & 50 \\
\hline
\end{tabular}

\section{RCM data}

Pro vyhodnocení účinku korekce systematických chyb simulovaných časových rad srážek a teploty na simulovaný odtok bylo uvažováno 52 simulací regionálních klimatických modelů z projektu CORDEX [12]. Přehled použitých simulací udává tabulka 1. K dispozici bylo sedm regionálních klimatických modelů k downscalingu simulací deseti globálních klimatických modelů. Z regionálních klimatických modelů je nejpočetněji zastoupen model RCA4 (30 simulací) a CLM (8 simulací). Simulace nejčastěji využívají koncentrační scénář RCP8.5 předpokládající nejintenzivnější zvyšování radiačního působení (26 simulací) a RCP4.5 (21 simulací), méně pak RCP2.6 předpokládající snižování koncentrací skleníkových plynů (3 simulace). Pro RCP6.0 nebyla dostupná žádná simulace. Simulace jsou většinou dostupné pro období cca 1961-2100, některé 1950-2100. Prostorové rozlišení je $0,11^{\circ}$ a $0,44^{\circ}$, což odpovídá cca 12 a $50 \mathrm{~km}$. Všechny simulace jsou volně dostupné prostřednictvím Earth System Grid Federation.

\section{METODIKA}

Pozorované časové řady srážek a teploty byly použity pro kalibraci hydrologického modelu Bilan (kap. Hydrologické modelování). Simulované časové řady srážek a teploty byly korigovány standardní a kaskádovou kvantilovou metodou (kap. Korekce systematických chyb). Vybrané charakteristiky rozdělení korigovaných srážek, teploty a odpovídajícího modelovaného odtoku byly porovnány (kap. Vyhodnocení) s charakteristikami pozorovaných veličin (srážek, teploty a odpovídajícího modelovaného odtoku). 

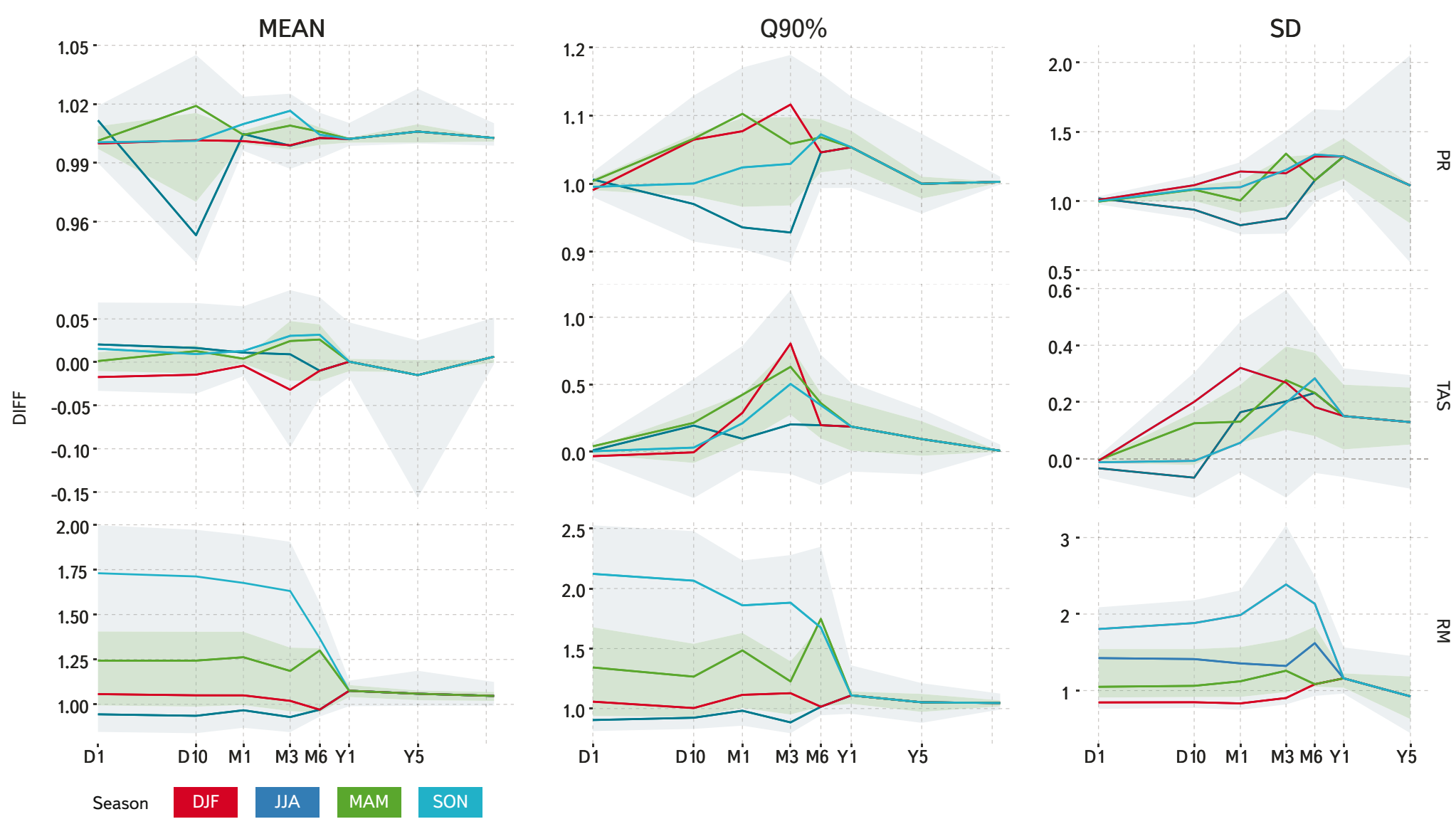

Obr. 1. Zbytková chyba (relativní pro srážky a odtok, absolutní pro teplotu $\left.\left[{ }^{\circ} \mathrm{C}\right]\right)$ po korekci standardní kvantilovou metodou pro průměr (vlevo), 90\% kvantil (uprostřed) a směrodatnou odchylku (vpravo), pro srážky (nahoře), teplotu (uprostřed) a modelovaný odtok (dole); barvy určují roční období (červená - zima, zelená - jaro, modrá - léto, světle modrá podzim); vodorovná osa značí časové agregace (D1 - den, D10 - deset dnů, M1 - měsíc, M3 - tři měsíce, M6 - šest měsíců, Y1 - rok, Y5 - pět let); čáry značí průměrnou chybu, zelený pás rozpětí $50 \%$ a modrý pás $90 \%$ ze všech modelů

Fig. 1. Residual error (relative for precipitation and runoff, absolute for temperature $\left[{ }^{\circ} \mathrm{C}\right]$ ) after the standard quantile correction method for mean (left), $90 \%$ quantile (middle) and standard deviation (right), for precipitation (top), temperature (middle) and simulated runoff (bottom); colours indicate seasons (red - winter, green - spring, blue - summer, light blue - autumn); horizontal axis shows time aggregation (D1 - a day, D10 - ten days, M1 - a month, M3 - three months, M6 - six months, $Y 1$ - a year, Y5 - five years); the lines represent mean residual error in the climate model ensemble, green (blue) area indicates an envelope of 50 (90)\% of climate model simulations

\section{Korekce systematických chyb}

Simulované časové řady srážek a teploty byly korigovány pomocí standardní kvantilové metody popsané např. [13]. Tato metoda zaručuje, že rozdělení pravděpodobnosti srážek a teploty korigovaných dat odpovídá rozdělení pravděpodobnosti pozorovaných veličin. Kvantilová metoda byla použita v denním kroku, zvlášt pro jednotlivé měsíce.

Za účelem vyhodnocení vlivu korigovaného časového měřítka na modelovaný průtok byla kvantilová metoda aplikována také iterativně pro různá časová měřitka (konkrétně denní, měsíční a roční) pomocí přístupu popsaného Haerterem aj. [9]. Podstatou metody je opakovaná korekce denních časových řad na základě rozdělení denních hodnot a měsíčních a ročních agregací. Vzhledem k tomu, že korekce $v$ jednom časovém měřítku ovlivňuje rozdělení $\checkmark$ jiných časových měřítcích, je postup iterativně opakován.

\section{Hydrologické modelování}

Simulace odtoku z povodí Oslavy byla provedena modelem Bilan vyvíjeným ve Výzkumném ústavu vodohospodářském (VúV). Bilan [14] je konceptuální model hydrologické bilance, který je v denním kroku řizen šesti parametry. Srážky jsou transformovány na odtok pomocí soustavy lineárních a nelineárních nádrží. Kalibrace parametrů modelu probíhá na pozorovaných časových řadách (srážky, teplota a odtok), kdy se sleduje nejlepši shoda mezi pozorovaným a modelovaným odtokem. Nakalibrovaným modelem se dále generuje odtok na základě korigovaných srážek a teploty vycházejících z RCM. Více o modelu lze nalézt na bilan.vuv.cz.

\section{Vyhodnocení}

K vyhodnocení zbytkové chyby $v$ korigovaných časových řadách srážek, teploty a modelovaného odtoku byl použit balík MUSICA pro prostředí R [15]. Balík umožňuje pohodlné porovnání libovolných charakteristik rozdělení hodnocených veličin pro rưzná časová měřitka, přičemž tato měřitka je možno uživatelsky definovat. V tomto článku jsou dále uvažována denní (D1), 10denní (D10), měsíční (M1), 3 a 6měsíční (M3 a M6) a roční a pětileté (Y1 a Y5) časové agregace. Pro kratší než půlroční agregace jsou výsledky prezentovány jako průměry pro jednotlivé sezony (MAM - březen, duben, květen; JJA - červen, červenec, srpen; SON - zárí, říjen, listopad; DJF - prosinec, leden, únor). Primárně se hodnotí chyba korigovaných veličin, která je dále označována jako „zbytková chyba”. 

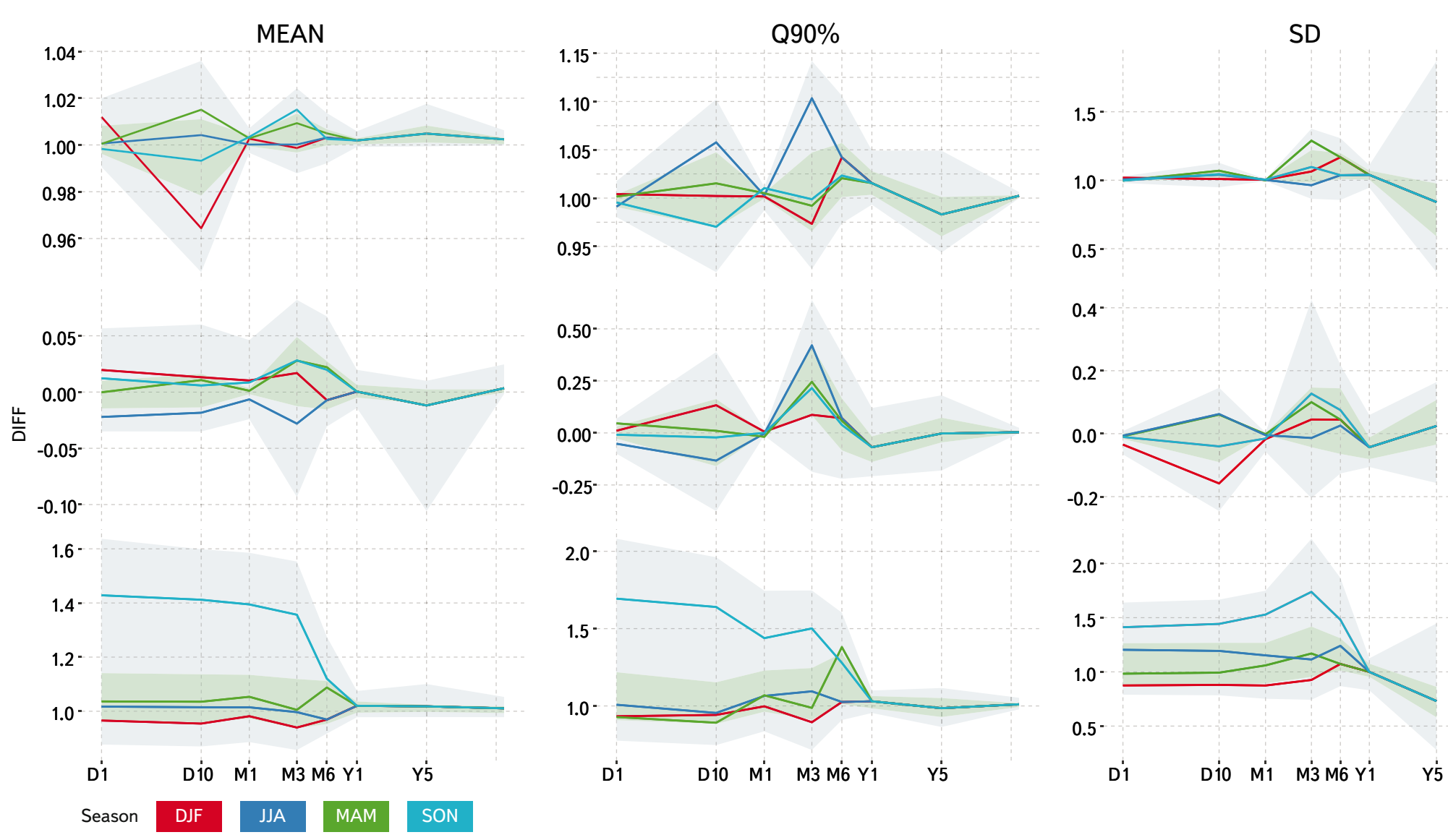

Obr. 2. Zbytková chyba (relativní pro srážky a odtok, absolutní pro teplotu [ [C]) po korekci kaskádovou kvantilovou metodou pro průměr (vlevo), 90\% kvantil (uprostřed) a směrodatnou odchylku (vpravo), pro srážky (nahoře), teplotu (uprostřed) a modelovaný odtok (dole); barvy určují roční období (červená - zima, zelená - jaro, modrá - léto, světle modrá podzim); vodorovná osa značí časové agregace (D1 - den, D10 - deset dnů, M1 - měsíc, M3 - tři měsíce, M6 - šest měsíců, Y1 - rok, Y5 - pět let); čáry značí průměrnou chybu, zelený pás rozpětí $50 \%$ a modrý pás $90 \%$ ze všech modelů

Fig. 2. Residual error (relative for precipitation and runoff, absolute for temperature $\left[{ }^{\circ} \mathrm{C}\right]$ ) after the cascade quantile correction method for mean (left), $90 \%$ quantile (middle) and standard deviation (right), for precipitation (top), temperature (middle) and simulated runoff (bottom); colours indicate seasons (red - winter, green - spring, blue - summer, light blue - autumn); horizontal axis shows time aggregation (D1 - a day, D10 - ten days, M1 - a month, M3 - three months, M6 - six months, Y1 - a year, Y5 - five years); the lines represent mean residual error in the climate model ensemble, green (blue) area indicates an envelope of 50 (90)\% of climate model simulations

\section{VÝSLEDKY}

Z obr. 1 a 2 je patrné, že pro všechny tři prezentované charakteristiky (průměr, 90\% kvantil a směrodatná odchylka) jsou zbytkové chyby velmi malé u srážek i teploty, zejména v D1 měřítku, pro které byly korekce kalibrovány. Nicméně v př́padě použití těchto srážek a teplot pro modelování odtoku dochází k „zesílení“ zbytkových chyb nad únosnou mez. Uspokojivé výsledky se nedostavily ani pro měřítko D1, pro které byly korekce kalibrovány. Extrémním prípadem je podzimní sezona (světle modře) - v absolutním vyjádření se však jedná o velmi malé hodnoty.

Korekce kaskádovou kvantilovou metodou (obr. 2) přináší výrazně lepší výsledky. Je vidět, že rozpětí chyb u srážek a teploty je v měřítcích M1 a Y1 podstatně nižší než v prípadě korekce standardní kvantilovou metodou (obr. 1). Bohužel u agregací D10, M3 a M6 se již tak výrazné zlepšení nevyskytuje, jelikož tyto nebyly zahrnuty do kaskádové korekce. Je zajímavé, že u modelovaného odtoku dochází k podstatnému snížení zbytkové chyby pro prezentované charakteristiky ve všech časových měřítcích.

Obr. 3 a 4 ukazují míru korelace mezi veličinami přes rưzná časová měřítka ve čtyřech sezonách. Lze pozorovat, že korelace pro odtok a srážku je pozitivní, naopak pro teplotu a srážku a odtok a teplotu je korelace spíše negativní. Ve všech prípadech míra korelace roste s časovým měřítkem. Dále je vidět, že základní průběh korelace mezi sledovanými veličinami zůstává zachován pro simulovaná i korigovaná data a použití metody korekce systematických chyb má malý vliv na korelační strukturu. Nicméně dochází ke zlepšení v případě použití kaskádové korekce, zejména u korelace mezi srážkou a odtokem, kde lze pozorovat těsnější vztah mezi korigovanými a pozorovanými daty.

\section{DISKUSE A ZÁVĚR}

Z prezentovaných výsledků je zřejmé, že korekce srážek a teploty pomocí standardní kvantilové metody není vhodná pro rutinní využití v hydrologických simulacích, jelikož $v$ některých ročních obdobích vede ke značné zbytkové chybě modelovaného odtoku ve všech časových měřitcích kratších než rok, včetně denních hodnot, na kterých byla korekce kalibrována. Podobné výsledky prezentuje i Teng aj. [16]. Relativně největší zbytkové chyby se vyskytují v období nízkých prưtoků (a v absolutním vyjádření se zpravidla jedná o nízké hodnoty).

Dalši výsledky (které nejsou kvưli rozsahu zahrnuty v tomto článku) ukazují, že podobné výsledky lze očekávat i u jiných povodí a při použití jiných hydrologických modelů. Východiskem může být využití nejnovějších (poměrně komplexních) metod popsaných Mehrotrou a Sharmou [17], které umožňují korigovat 


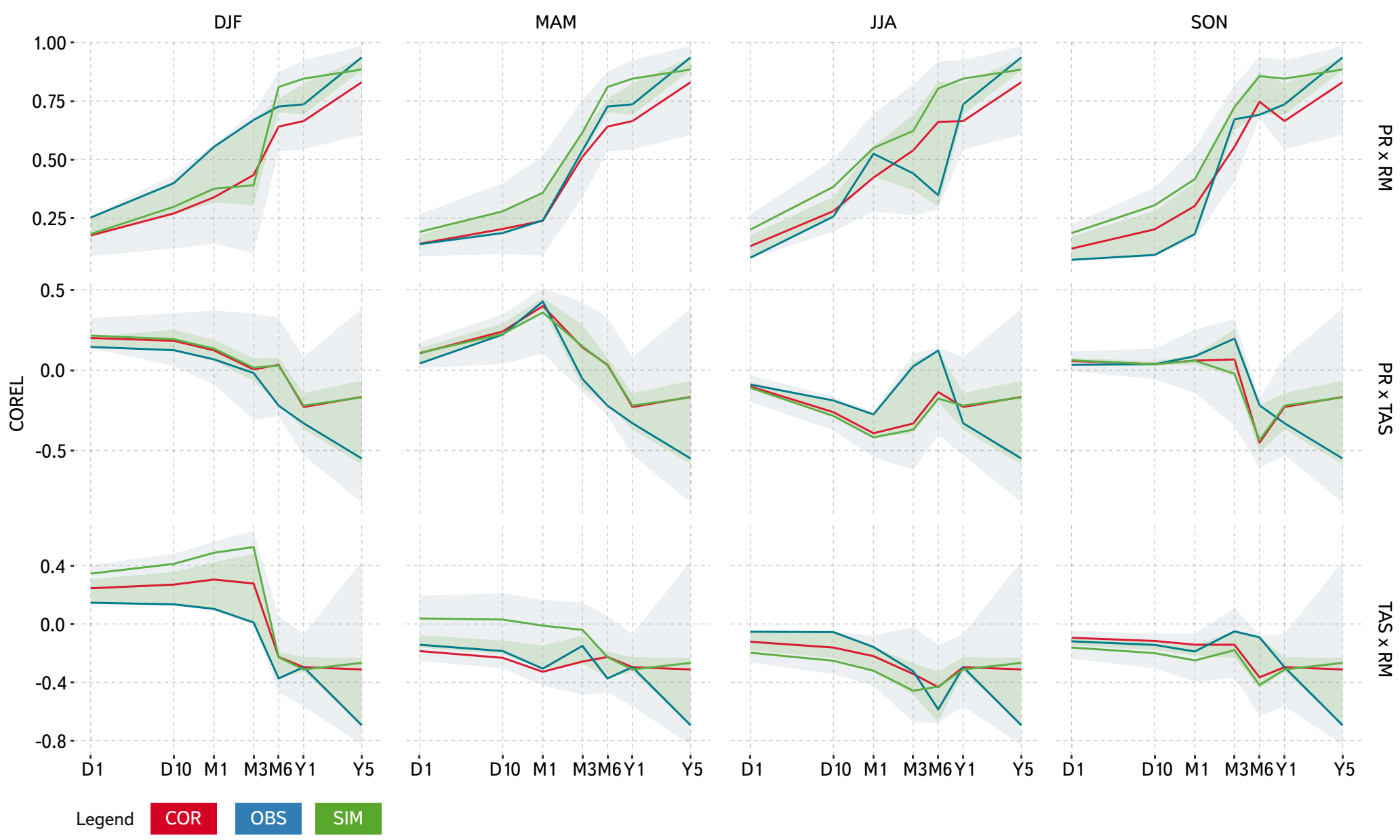

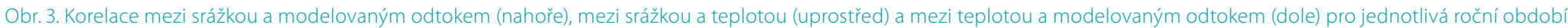

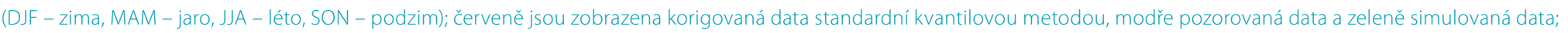

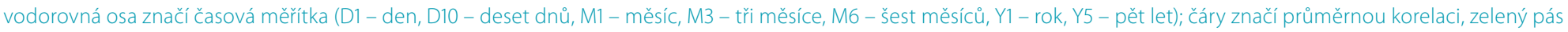
rozpětí 50 \% a modrý pás $90 \%$ ze všech modelů

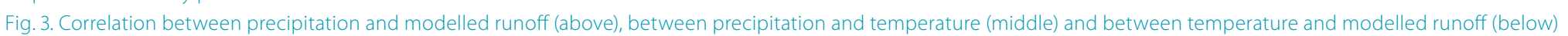

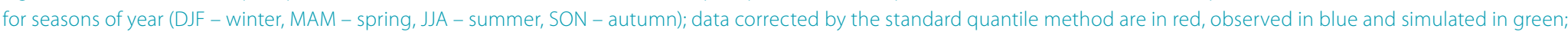

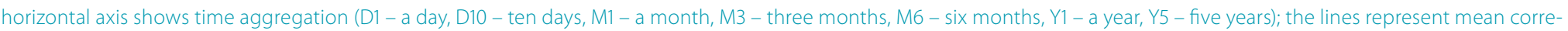
lation coefficient, green (blue) area indicates an envelope of 50 (90)\% of climate model simulations

rozdělení pravděpodobnosti a korelační a autokorelační strukturu pro veličiny v různých časových měřítcích. Úspěšnost těchto metod při hydrologických simulacích není nicméně zatím známa. Druhou možností je využití kombinací jednoduchých metod (např. prrírůstková metoda, popř. aplikovaná v různých časových měřítcích) v kombinaci se stochastickými metodami umožňujícími generování dlouhodobé variability [18].

\section{Poděkování}

Tento článek vznikl v rámci řešení projektu "Možnosti kompenzace negativních dopadů klimatické změny na zásobování vodou a ekosystémy využitím lokalit vhodných pro akumulaci povrchových vod" (TA04020501), který je spolufinancován Technologickou agenturou České republiky, a projektu "Pưdní a hydrologické sucho v měnícím se klimatu" (1616549S) financovaném Grantovou agenturou České republiky.

\section{Literatura}

[1] BROCKHAUS, P., LÜTHI, D., and SCHÄR, C. Aspects of the diurnal cycle in a regional climate model Meteorol. Z., 2008, 17, p. 433-443, doi: 10.1127/0941-2948/2008/0316.

[2] HOHENEGGER, C., BROCKHAUS, P., a SCHÄR, C. Towards climate simulations at cloud-resolving scales. Meteorol. Z., 2008, 17, p. 383-394, doi:10.1127/0941-2948/2008/0303.

[3] KENDON, E.J., ROBERTS, N.M., SENIOR, C.A., and ROBERTS, M.J. Realism of rainfall in a very high-resolution regional climate model. J. Climate, 2012, 25, p. 5791-5806, doi:10.1175/JCLI-D-11-00562. 1.

[4] MAURAN, D., WETTERHALL, F., IRESON, A.M., CHANDLER, R.E., et. al. Precipitation downscaling under climate change: recent developments to bridge the gap between dynamical models and the end user. Reviews of Geophysics, 2010, 48(3):RG3003, doi:10.1029/2009RG000314.

[5] TEUTSCHBEIN, C. and SEIBERT, J. Bias correction of regional climate model simulations for hydrological climate-change impact studies: Review and evaluation of different methods. Journal of Hydrology, 2012, 456-457, p. 12-29, doi:10.1016/j.jhydrol.2012. 05. 052.

[6] MAURAN, D., WIDMANN, M., GUTIÉRREZ, J.M., et. al. VALUE: a framework to validate downscaling approaches for climate change studies. Earth's Future, 2015, 3, p. 1-14, doi: 10.1002/2014EF000259.

[7] EHRET, U., ZEHE, E., WULFMEYER, V., et al. Hess opinions „should we apply bias correction to global and regional climate model data?" Hydrology and Earth System Sciences, 2012, 16, p. 3391-3404

[8] ADDOR, N., ROHRER, M., FURRER, R., and SEIBERT, J. Propagation of biases in climate models from the synoptic to the regional scale: Implications for bias adjustment. Journal of Geophysical Research Atmospheres, 2016, 121(5),p. 2075-2089, doi:10.1002/2015JD024040. 

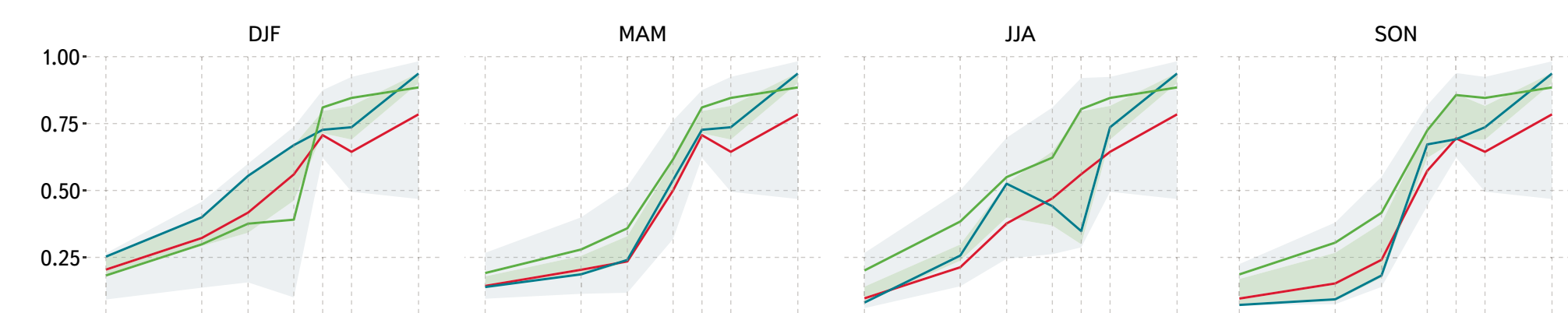

$\frac{0}{0}$
$\times$
$\frac{\pi}{3}$
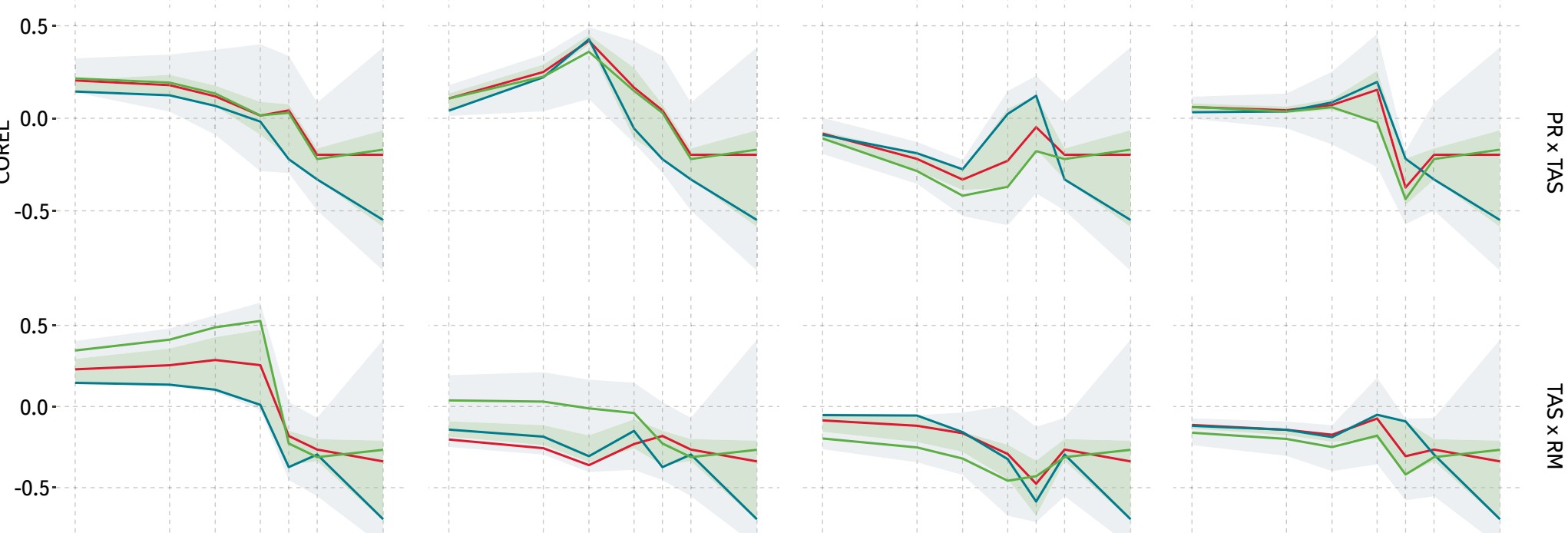

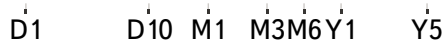

\section{D'1}
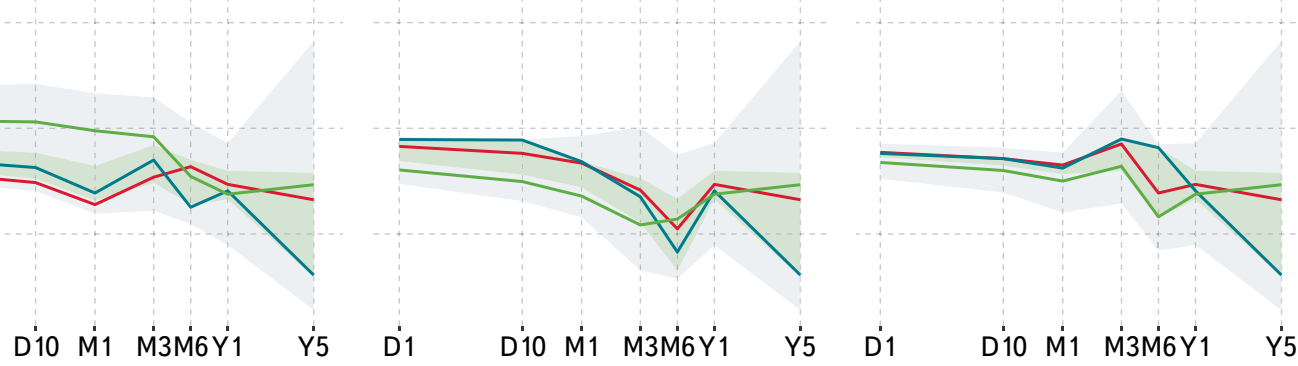

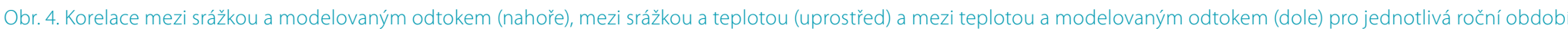

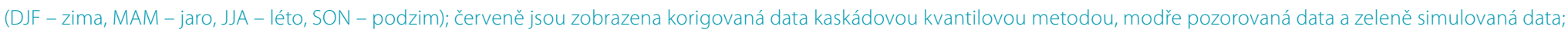

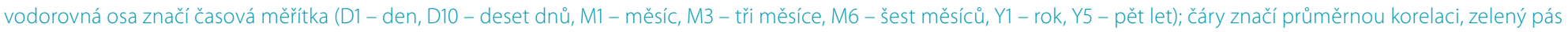
rozpětí 50 \% a modrý pás $90 \%$ ze všech modelů

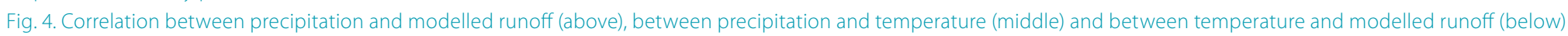

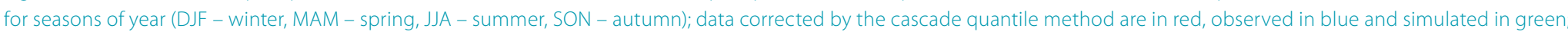

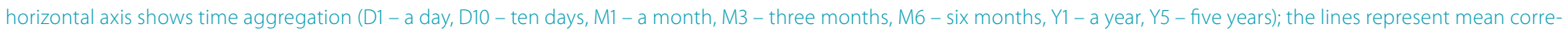
lation coefficient, green (blue) area indicates an envelope of 50 (90)\% of climate model simulations

[9] HAERTER, J. HAGEMANN, S., MOSELEY, C., and PIANI, C. Climate model bias correction and the role of timescales. Hydrology and Earth System Sciences, 2011, 15, p. 1065-1079.

[10] JOHNSON, F. and SHARMA, A. A nesting model for bias correction of variability at multiple time scales in general circulation model precipitation simulations. Water Resources Research, 2012, 48.

[11] ŠTĚPÁNEK, P., ZAHRADNIČEK, P., and HUTH, R. Interpolation techniques used for data quality control and calculation of technical series: an example of a Central European daily time series. IDÖJÁRÁS - Quaterly Journal of the Hungarian Meteorological Service, 2011, 115 (1-2), p. 87-98.

[12] JACOB, D., PETERSEN, J., EGGERT, B., et. al. EURO-CORDEX: new high-resolution climate change projections for European impact research. Regional Environmental Change, 2014, 14(2), p. 563-578, doi:10.1007/s10113-013-0499-2

[13] GUDMUNDSSON, L., BREMNES, J.B., HAUGEN, J.E., and ENGEN-SKAUGEN, T. Technical Note: Downscaling RCM precipitation to the station scale using statistical transformations - a comparison of methods. Hydrol. Earth Syst. Sci., 2012, 16, p. 3383-3390, doi: 10.5194/hess-16-3383-2012.

[14] VIZINA, A., HORÁČEK, S. a HANEL, M. Nové možnosti modelu BILAN. VTEl, 2015, 57, č. 4-5, ISSN 0322-8916.

[15] HANEL, M. a KOŽÍN, R. Bias and changes in climate model simulations at multiple time scales, 2016, v přípravě.

[16] TENG, J., POTTER, N.J., CHIEW, F.H.S., ZHANG, L., et. al. How does bias correction of regional climate model precipitation affect modelled runoff? Hydrol. Earth Syst. Sci., 2015, 19, p. 711-728, doi:10.5194/ hess-19-711-2015.
[17] MEHROTRA, R. and SHARMA, A. A multivariate quantile-matching bias correction approach with auto-and cross-dependence across multiple time scales: Implications for downscaling. Journal of Climate, 2016, 29, p. 3519-3539, doi:10.1175/JCLI-D-15-0356. 1.

[18] KOUTSOYIANNIS, D., EFSTRATIADIS, A., and GEORGAKAKOS, K.P. Uncertainty Assessment of Future Hydroclimatic Predictions: A Comparison of Probabilistic and Scenario-Based Approaches. Journal of Hydrometeorology, 2007, 8:3, p. 261-281, doi: 10.1175/JHM576. 1. 


\section{Autoři}

doc. Ing. Martin Hanel, Ph.D.,

凶martin_hanel@vuv.cz

Ing. Roman Kožín ${ }^{1,2}$

凶roman_kozin@vuv.cz

'Výzkumný ústav vodohospodářský T. G. Masaryka, v. v. i.

${ }^{2}$ Česká zemědělská univerzita v Praze, Fakulta životního prostředí

Příspěvek prošel lektorským řízením.

\section{BIAS CORRECTION OF PRECIPITATION AND TEMPERATURE FROM REGIONAL CLIMATE MODELS - THE IMPACT ON RUNOFF MODELLING}

\section{HANEL, M.1,2; KOZIN, R. ${ }^{1,2}$}

'TGM Water Research Institute, p. r. i.

${ }^{2}$ Czech University of Life Sciences Prague, Faculty of Environmental Sciences

Keywords: bias correction - quantile method climate scenarios - runoff modelling

Hydrological modelling is often used for assessment of climate change impacts on water resources. Inputs into the hydrological model are represented by precipitation and temperature based on simulations of climate models. These models are biased and therefore some of the available bias-correction methods have to be applied on before using the simulated data in hydrological model. However, it is shown that identity of distributions of corrected and observed inputs (precipitation and temperature) does not guarantee identity of distributions of outputs (runoff). This is especially due to the fact, that generally used methods for correction of systematical biases of climate models do not eliminate errors in temporal structure of precipitation. Another issue is, that the corrections are usually focused only on time scale in which the hydrological model is operated, e.g. 1 day. Despite the satisfactory correction of variables in daily time step, monthly, seasonal and annual aggregations of precipitation appear to be biased, which consequently results in errors in long-term hydrological balance and variablity of simulated runoff. 